\title{
“MENUJU TARAKAN ZERO WASTE “ PENGELOLAAN SAMPAH PLASTIK DENGAN METODE ECOBRICK DI KELURAHAN SELUMIT PANTAI TARAKAN TENGAH
}

\author{
Tuty Alawiyah, Gandri Haryono, Boy Putra
}

Manajemen Sumberdaya Perairan, Fakultas Perikanan dan Ilmu Kelautan Universitas Borneo Tarakan

Jl. Amal Lama Nomor 1 Kelurahan Pantai Amal Lama, Tarakan - 77123 PO BOX 170

*Alamat korespondensi : tutyalawiyah@borneo.ac.id

\begin{tabular}{ll}
\hline Keyword: & Abstrak: \\
Ecobrick, & Pengelolaan sampah perkotaan masih menjadi permasalahan yang sulit dipecahkan \\
Sampah & oleh pemerintah. Pengangkutan sampah hanya berkisar dari $60-70 \%$ yang dapat \\
Plastik, & diangkut ke TPA sisanya tercecer begitu saja di lingkungan sekitar perumahan \\
Selumit & penduduk. Selumit Pantai adalah salah satu Kelurahan tepatnya di Tarakan Tengah, \\
Pantai & Kota Tarakan Provinsi Kalimantan Utara yang termasuk kawasan padat penduduk \\
& mencapai 16.347 jiwa dengan luas wilayah hanya 0,48 km2 hal ini berdampak pada \\
& volume sampah yang dihasilkan dari aktivitas penduduk. Pada pengabdian ini akan \\
& dilakukan pengelolaan sampah plastik dengan pendekatan metode Ecobrick yang \\
& tidak memerlukan teknologi tinggi dan biaya. Prinsip dari metode Ecobrick adalah \\
& botol plastik diisi dengan bahan padatan berupa sampah plastik atau sampah \\
& anorganik hingga benar-benar keras dan padat yang dapat dimanfaatkan untuk \\
& pembuatan meja, kursi, tembok atau barang kesenian lainnya. Tujuan dari ecobrick \\
& adalah untuk mengurangi sampah plastik yang dapat dijadikan sebagai bahan yang \\
& berguna. Sasaran kegiatan ini adalah ibu-ibu rumah tangga di Kelurahan Selumit \\
& Pantai. Tahapan kegiatan meliputi sosialisasi sampah plastik, Pelatihan Pengelolaan \\
& Sampah Metode Ecobrick, Pendampingan pembuaatan Ecobrik, Evaluasi. Hasil \\
& pengabdian masyarakat menunjukkan ketercapaian kegiatan dalam pengelolaan \\
& sampah dengan metode Ecobrick mencapai $90 \%$. Hal ini digambarkan dari \\
& antusiasme ibu-ibu rumah tangga yang ingin memanfaatkan sampah yang ada \\
& dilingkungan sehingga memiliki nilai guna. Ketercapaian ini juga dilihat dari \\
& pemahaman narasumber dalam memberikan materi dan pendampingan pada \\
& peserta mencapai $85 \%$.
\end{tabular}

Panduan Sitasi (APPA $7^{\text {th }}$ edition) :

Alawiyah, T., Haryono, G., \& Putra, B. (2022). “Menuju Tarakan Zero Waste “ Pengelolaan Sampah Plastik Dengan Metode Ecobrick Di Kelurahan Selumit Pantai Tarakan Tengah. Jurnal Pengabdian Perikanan Indonesia, 2(1), 45-50. https://doi.org/10.29303/jppi.v2i1.505. 


\section{PENDAHULUAN}

Pengelolaan sampah perkotaan masih menjadi permasalahan yang sulit dipecahkan oleh pemerintah. Penanganan sampah yang sudah dilakukan oleh pemerintah saat ini adalah dengan melakukan pengumpulan sampah disetiap rumah kemudian dilanjutkan dengan proses pengangkutan ke landfill atau biasa disebut Tempat Pembuangan Akhir (TPA). Pengangkutan sampah hanya berkisar dari 60-70\% yang dapat diangkut ke TPA sisanya tercecer begitu saja di lingkungan sekitar perumahan penduduk.

Tarakan merupakan sebuah kota terbesar yang ada di Provinsi Kalimantan Utara dengan jumlah penduduk 246.720 jiwa. Kota Tarakan terdapat Bandara International dan pelabuhan besar yang menjadi moda transportasi antar pulau sehinga Tarakan menjadi tempat persinggahan atau transit bagi yang akan melanjutkan perjalanan. Tarakan sebagai kota yang ramai dikunjungi meskipun hanya sekedar singgah. Melihat kondisi tersebut tidak bisa dipungkiri akan menimbulkan dampak samping salah satunya adalah volume sampah yang dihasilkan tentu saja menjadi lebih banyak karena selain penduduk asli Tarakan terdapat juga pendatang yang transit sebagai salah satu penyumbang sampah. Beberapa sumber sampah yang ada di Kota Tarakan antara lain berasal dari kegiatan seharihari penduduk Kota Tarakan, sampah yang berasal dari pusat perbelanjaan, pasar, rumah makan, restoran, hotel, tempat wisata, sekolah, perkantoran, bandara, pelabuhan, rumah sakit, industri, serta jalan. Mengingat pertumbuhan penduduk yang semakin meningkat hal ini pasti akan berpengaruh terhadap volume sampah yang dihasilkan. Pada harian online Tribun Kaltim menyatakan bahwa volume sampah yang dihasilkan setiap hari mencapai 140 ton dimana terdapat penambahan sebesar 20 ton per hari, hal ini disebabkan karena adanya peningkatan jumlah penduduk.

Selumit Pantai adalah salah satu Kelurahan di Kecamatan Tarakan Tengah, Kota Tarakan Provinsi Kalimantan Utara. Selumit Pantai salah satu kelurahan yang padat penduduk mencapai 16.347 jiwa dengan luas wilayah hanya $0,48 \mathrm{~km}^{2}$. Selain padat penduduk Selumit Pantai juga ramai karena adanya perumahan dan pertokoan. Selumit pantai termasuk kategori kawasan kumuh berdasarkan pada surat keputusan Walikota Tarakan, kawasan kumuh Kota Tarakan seluas kurang lebih 33,4 hektar yang tersebar pada 4 kelurahan, salah satunya adalah Kelurahan Selumit Pantai. Suasana kondisi permukiman para warga yang hidup di sana sangat memprihatinkan. Tampak lingkungan permukiman terlihat sumpek, tidak nyaman dan tidak sehat sebab tidak dilengkapi dengan prasarana dan sarana pendukung yang layak seperti akses jalan, sanitasi dan air bersih. Selain itu kondisi pembuangan sampah di Selumit Pantai juga sangat memprihatinkan karena sampah dibuang begitu saja dibawah kolong tempat tinggal penduduk sehingga timbunan sampah tersebut menyebabkan bau yang tidak sedap bahkan jika banjir dapat menyebabkan sampah-sampah tersebut akan terbawa arus menuju laut, hal ini yang akan berdampak pada pencemaran laut. Oleh karena itu perlu dilakukan upaya untuk mengatasi permasalahan tersebut.

Salah satu upaya yang akan dilakukan pada pengabdian ini yaitu melakukan pengelolaan sampah plastik dengan pendekatan metode Ecobrick yang tidak memerlukan teknologi dan biaya. Prinsip dari metode Ecobrick adalah botol plastik yang diisi dengan bahan padatan berupa sampah plastik atau sampah anorganik hingga benar-benar keras dan padat sehingga dapat dimanfaatkan untuk pembuatan meja, kursi, tembok atau barang kesenian lainnya. Tujuan dari ecobrick adalah untuk mengurangi sampah plastik yang dapat dijadikan sebagai bahan yang berguna. Sasaran kegiatan ini adalah ibu-ibu-ibu rumah tangga di Kelurahan Selumit Pantai, dengan alasan karena ibu rumah tangga yang paling banyak menggunakan plastik dalam menjalankan aktivitas sehari-hari, pemberian stimulus ini diharapakan dapat meminimalisir volume sampah yang ada di Kota Tarakan khususnya di Kelurahan Selumit Pantai. 
Pengelolaan sampah masih menjadi masalah yang belum sepenuhnya bisa diatasi. Permasalahan sampah muncul karena beberapa faktor seperti kurangnya wawasan masyarakat terhadap dampak yang ditimbulkan akibat penggunaan plastik secara berlebih, kurangnya pemahaman masyarakat terhadap pemilahan sampah yaitu jenis sampah yang bersifat biodegradable dan non biodegradable sehingga hal ini yang menyebabkan masyarakat cenderung untuk membuang sampah sembarangan, selain itu kurangnya pemahaman masyarakat terhadap pengelolaan sampah secara sederhana. Hal tersebut menjadi dasar untuk melaksanakan kegiatan pemberdayaan masyarakat yaitu untuk meningkatkan pengetahuan masyarakat terhadap sampah dan pengelolaan sampah. Permasalahan sampah di Kelurahan Selumit Pantai tidak bisa dibiarkan terus menerus sehingga harus ada upaya yang dilakukan untuk meminimalkan volume sampah. Adapun solusi yang akan ditawarkan kepada mitra sasaran dibagi menjadi beberapa tahapan kegiatan antara lain sosialisasi terkait sampah, pelatihan pengelolaan sampah dengan metode ecobrick, pendampingan pembuatan ecobrick, serta evaluasi kegiatan. Kegiatan pemberdayaan ini diharapkan dapat meningkatkan wawasan masyarakat terkait sampah dan pengelolaannya. Target sasaran pada pengabdian masyarakat ini adalah ibu-ibu rumah tangga yang menjadi pengguna sampah terbesar.

\section{METODE KEGIATAN}

Adapun metode pelaksanaan pengabdian yang akan dilakukan di Kelurahan Selumit Pantai yaitu :

\section{Tahap 1. Sosialisasi Sampah Plastik}

Tujuan kegiatan sosialisasi sampah plastik adalah untuk meningkatkan wawasan dan pengetahuan masyarakat terkait sampah plastik, sifat sampah plastik, sumber sampah plastik, dampak terhadap lingkungan dan manusia yang ditimbulkan dari penggunaan sampah plastik secara berlebih, serta pengelolaan sampah plastik secara sederhana. Kegiatan sosialisasi ini melibatkan salah satu RT yang ada kelurahan Selumit Pantai yaitu RT 16. Sasaran sosialisasinya yaitu ibu-ibu rumah tangga yang dianggap paling banyak menggunakan plastik untuk aktivitas sehari-hari. Kegiatan ini akan dilaksanakan dengan mengundang ibu-ibu rumah tangga di RT 16, selain itu kegiatan ini akan melibatkan Bapak Lurah setempat untuk membuka kegiatan pengabdian ini. Untuk pelaksanaan kegiatan di masa pandemi Covid 19 akan di sesuaikan dengan protokoler kesehatan.

\section{Tahap 2. Pelatihan Pengelolaan Sampah Metode Ecobrick}

Tujuan kegiatan ini adalah melatih ibu-ibu rumah tangga dalam melakukan pengelolaan sampah yang sederhana dan tidak membutuhkan modal yang besar. Pelatihan ini akan dilaksanakan di salah satu rumah warga dengan tetap mengikuti protokoler kesehatan

\section{Tahap 3. Pendampingan Ecobrik}

Tujuan kegiatan ini adalah untuk menindaklanjuti kegiatan pelatihan sebelumnya. Ibu-ibu rumah tangga akan didampingi dalam proses pembuatan ecobrik sampai menghasilkan produk yang dikreasikan sendiri oleh ibu-ibu rumah tangga, sehingga kegiatan ini dapat menghasilkan produk yang nantinya apakah bisa bernilai ekonomis atau hanya diperuntukkan untuk keperluan rumah tangga

\section{Tahap 4. Evaluasi}

Tujuannya adalah untuk mengetahui sejauh mana keseriusan ibu-ibu rumah tangga di dalam pengelolaan sampah plastik menggunakan metode ecobrick. Evaluasi dilakukan dengan penyebaran 
quisioner kepada ibu-ibu rumah tangga yang sudah mengikuti kegiatan ini, sehingga kegiatan ini kedepannya dapat juga dilaksanakan di RT-RT lainnya.

\section{HASIL DAN PEMBAHASAN}

Kegiatan pengabdian kepada masyarakat dengan judul menuju tarakan zero waste “ pengelolaan sampah plastik dengan metode ecobrick di kelurahan selumit pantai Tarakan Tengah bertujuan untuk meningkatkan wawasan ibu-ibu rumah tangga di RT 16 Kelurahan Selumit Pantai terkait sampah plastik dan pengelolaannya sehingga dapat memberikan solusi untuk mengurangi volume sampah plastik di Kelurahan Selumit Pantai. Adapun kegiatan yang dilakukan yaitu sosialisasi tentang sampah plastik, pelatihan pembuatan ecobrick, pendampingan pembuatan ecobrik. Sosialisasi sampah plastik bertujuan untuk memberikan pemahaman kepada masyarakat seperti apa itu sampah plastik, jenis-jenis sampah plastik, dampah sampah plastik bagi lingkungan dan diri sendiri. Pada saat sosialisasi juga disampaikan beberapa teknik pengelolaan sampah plastik yang aman bagi lingkungan salah satunya adalah metode ecobrick. Ibu-Ibu Rumah Tangga RT 16 bersama Ibu Ketua RT memiliki antusias yang tinggi karena metode pengelolaan sampah dengan metode ecobrick mampu mengkreasikan sampah menjadi peralatan yang dapat bermanfaat. Adapun beberapa kegiatan yang sudah dilakukan dapat dilihat pada gambar berikut :

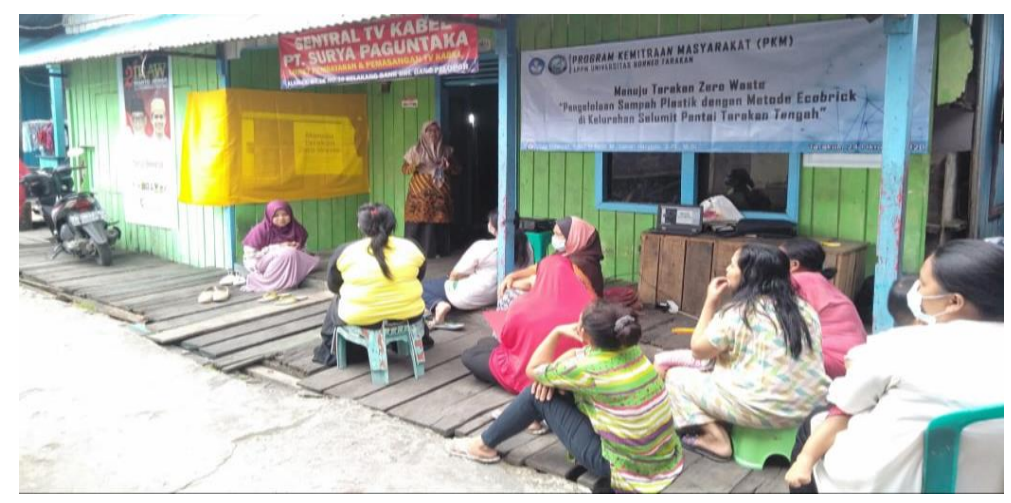

Gambar 1. Sosialisasi sampah plastik kepada ibu-ibu RT 16

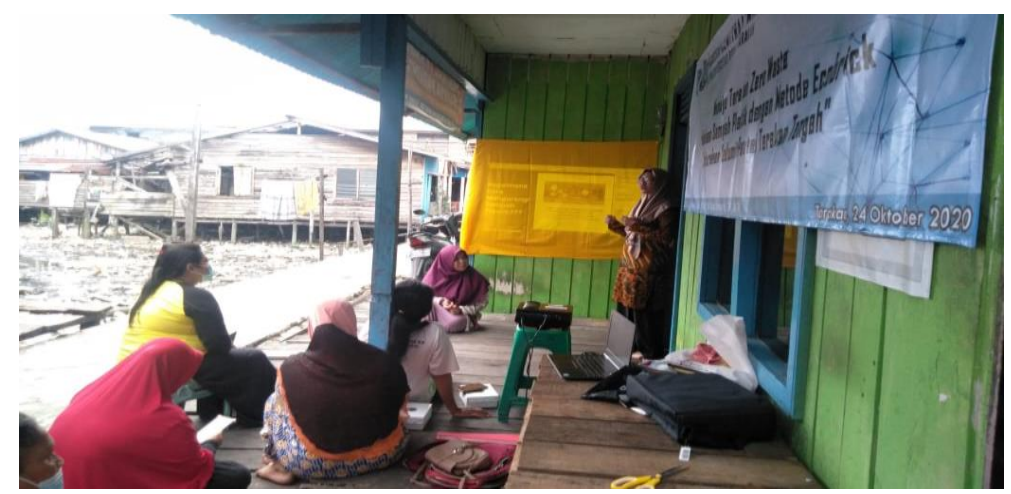

Gambar 2. Pelatihan pembuatan Ecobrick

Pelatihan pembuatan ecobrick dilakukan disalah satu rumah warga RT 16. Pelatihan ini bertujuan untuk meningkatkan kreativitas ibu-ibu rumah tangga khususnya RT 16 sehingga dapat melakukan pengolahan sampah plastik menjadi barang yang bermanfaat seperti meja, kursi, rak, dan sebagainya. Ibu-ibu antusias dalam pelaksanaan kegiatan pelatihan pembuatan ecobrick. 


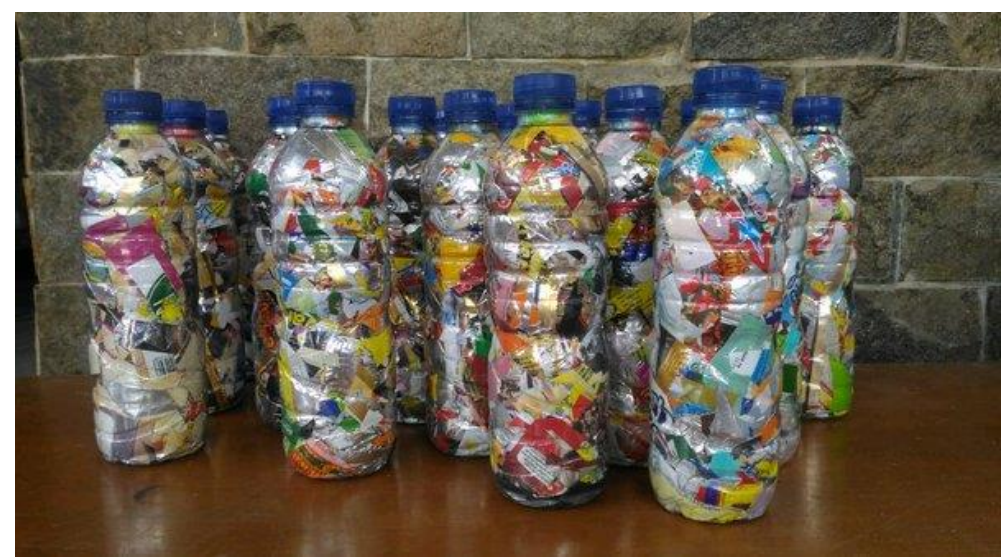

Gambar 3. Pembuatan Ecobrick

Pada proses pembuatan ecobrick tahapan yang dilakukan antara lain :

1. Ibu-ibu RT 16 yang berjumlah 20 orang diminta untuk mengumpulkan sampah plastik termasuk botol plastik yang digunakan setiap hari untuk pembuatan ecobrick. Proses ini berlangsung selama kurang lebih 2 minggu

2. Setelah sampah plastik terkumpul dimulai pembuatan ecobrick dirumah masing-masing

3. Setelah satu bulan dibulan oktober tim melakukan kunjungan untuk mengetahui kemajuan hasil yang diperoleh dari pembuatan ecobrick

Dari hasil kegiatan yang sudah dilakukan diperoleh produk berupa ecobrick yang dapat dipergunakan untuk keperluan sehari-hari. Setelah kegiatan PKM selesai dilaksanakan masyarakat mengharapkan ada tindak lanjut lagi terhadap kegiatan ini sampai benar-benar menghasilkan produk jadi yang bernilai ekonomi

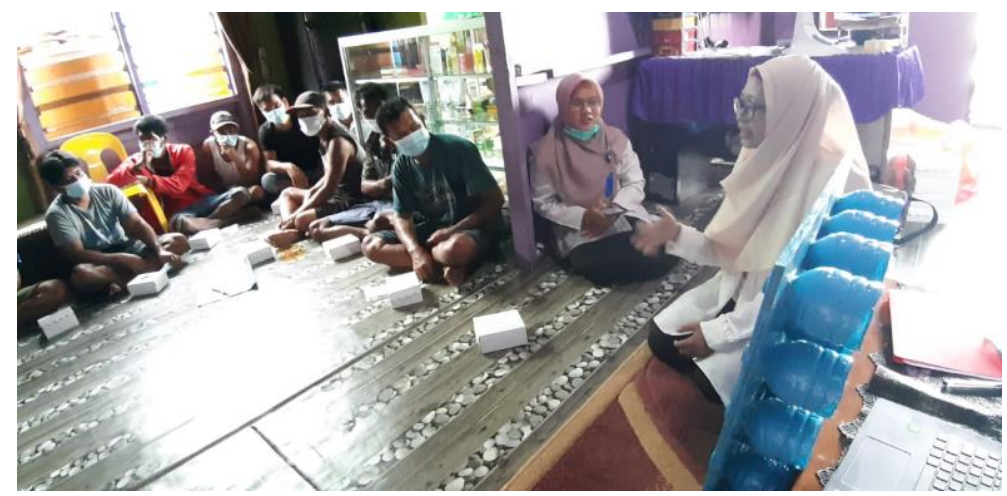

Gambar 4. Produk Ecobrick yang dihasilkan

\section{KESIMPULAN DAN SARAN}

Kesimpulan hasil kegiatan pengabdian yang telah dilakukan adalah metode ecobrick merupakan salah satu metode yang dapat digunakan untuk mengatasi permasalahan sampah khususnya sampah plastik.

Saran untuk keberlanjutan kegiatan pengabdian dalam pengelolaan limbah plastik perlu dilakukan pengembangan kreativitas sehingga kegiatan ini memiliki nilai ekonomis bagi masyarakat

\section{UCAPAN TERIMAKASIH}

Penulis mengucapkan terimakasih kepada LPPM Universitas Borneo Tarakan yang sudah membantu pembiayaan kegiatan Pengabdian Kepada Masyarakat dalam program hibah DIPA UBT 
Tahun 2020, Program Studi Manajemen Sumberdaya Perairan Fakultas Perikanan dan Ilmu Kelautan Universitas Borneo Tarakan yang memberikan ruang kepada penulis sehingga dapat berkontribusi dalam pengabdian kepada masyarakat.

\section{DAFTAR PUSTAKA}

Penanganan Kawasan Kumuh (n,d). Diakses tgl 28 September 2020, dari https://www.kompasiana.com/sahrilpercikan/580c4f6dd87a612f12e7250f/penanganankawasan-kumuh-wilayah-pesisir-ala-kota-tarakan?page=all

https://kaltim.tribunnews.com/2020/01/15/kurangi-beban-tpa-di-kota-tarakan-pemkot-genjotpengoperasian-tps-3r?page $=4$

Sampah Berserakan di Permukiman (n.d), 2018. Diakses tgl 29 Oktober 2018, dari https://www.jpnn.com/foto/daerah/21063/sampah-berserakan-dipermukiman

Banyak warga pesisir buang sampah, (2017). Diakses tgl 28 Oktober 2020, dari https://kaltara.prokal.co/read/news/8913-banyak-warga-pesisir-buang-sampah-ke-laut/1

Sampah Pesisir disorot komitmen masarakat dipertanyakan (n.d), 2018. Diakses tgl 28 Oktober 2020, dari https://benuanta.co.id/index.php/2019/11/18/sampah-pesisir-disorot-komitmenmasyarakat-dipertanyakan/5077/14/15/03/

Warga Selumit Pantai Mengeluhkan Sampah (n.d), 2018, diakses tgl 28 Oktober 2020, dari https://www.korandigitalnet.com/2018/04/warga-selumit-pantai-mengeluhkansampah.html

Radar Kaltara. Permukiman Kumuh Tarakan (n.d), 2019, diakses tgl 28 Oktober 2020, dar https://kaltara.prokal.co/read/news/25730-tarakan-permukiman-kumuh-terbanyak/6

Imron, M. (2020). diakses tgl 28 Oktober 2020, dari https://zerowaste.id/manajemensampah/ecobricks/

https://kaltim.tribunnews.com/2020/01/15/kurangi-beban-tpa-di-kota-tarakan-pemkot-genjotpengoperasian-tps-3r?page $=4$

https://www.jpnn.com/foto/daerah/21063/sampah-berserakan-dipermukiman

https://www.kompasiana.com/sahrilpercikan/580c4f6dd87a612f12e7250f/penanganan-kawasankumuh-wilayah-pesisir-ala-kota-tarakan?page=all 